DEPARTMENT OF THE INTERIOR

UNITED STATES GEOLOGICAL SURVEY

\title{
AEROMAGNETIC MAP OF WESTERN DORCHESTER COUNTY, MARYLAND, AND PARTS OF ADJACENT COUNTIES
}

Prepared in cooperation with the

MARYLAND GEOLOGICAL SURVEY 